\title{
Unwinding
}

\section{Rob Conkie}

To cite this article: Conkie, R. (2021). Unwinding. In F. Collins, H. Joyce and N. Maloney (Eds.) The Place of Writing in Intercultural and Intermedial Creative Collaborations. TEXT Special Issue 62. 


\title{
La Trobe University
}

\section{Rob Conkie}

\section{Unwinding}

\begin{abstract}
:
Here's my iteration of the Laocoön - shall we say? - meme. Does it begin with the sculpture described by Pliny the Elder and literally unearthed in a Roman vineyard in 1506 ? Or with the second book of Virgil's Aeneid? An eighteenth and nineteenth century touchstone for art/scholarship: I copy (do I copy?) Blake's engraving - image and text - as he had copied (no, not copied) a London-bound copy of the Rome-based "original". Poem > sculpture > painting $>$ art theory $>$ reproduction $>$ iPad Pro Procreate remediation.
\end{abstract}

\section{Biographical note:}

Rob Conkie, for the most part, works on Shakespeare in performance. He's the author of several books, Writing performative Shakespeares: New forms for performance criticism (2016) among them. He is currently preoccupied with the new form of image/texts, especially as they might remediate live theatrical performance.

Keywords:

Laocoön, image/text, intermediality, William Blake 


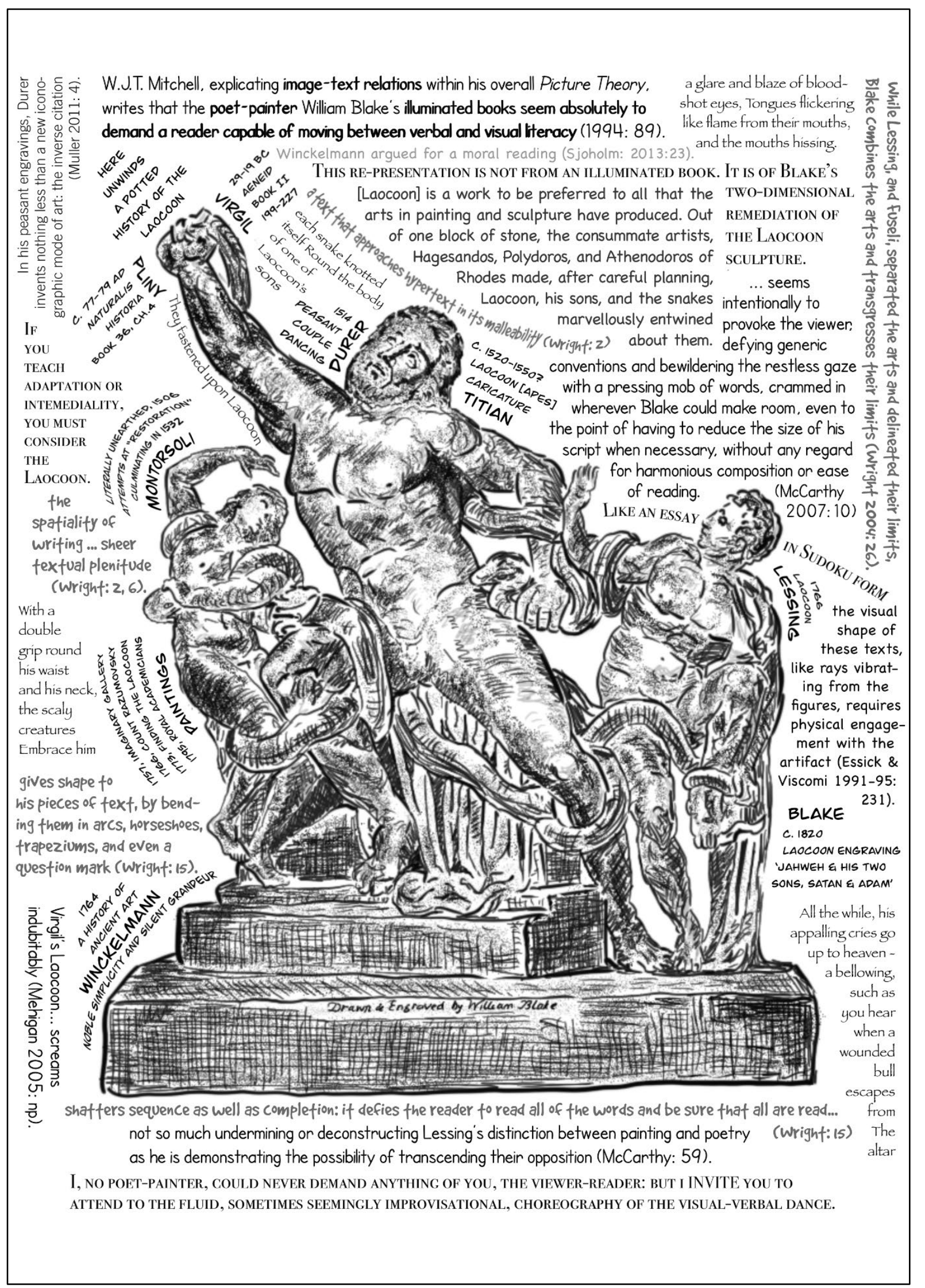

TEXT Special Issue 62: The Place of Writing in Intercultural and Intermedial Creative Collaborations eds Felicity Collins, Hester Joyce \& Noel Maloney, October 2021 


\section{References}

Blake, W. (c. 1820-1850). The Laocoön, engraved plate.

Essick, R., \& Viscomi, J. (Eds.). (1991-5). Milton: A poem. By William Blake. In R. Bindman (Ed.), Blake's illuminated books (Vol 5). The Blake Trust/Princeton University Press.

McCarthy, E. (2007). William Blake's Laocoön: The genealogy of a form. PhD Thesis, University of Kansas.

Mehigan, T. (2005). Lessing's Laocoön and the rhetoric of pain. Double dialogues 6, unpaginated.

Mitchell, W. J. T. (1995). Picture theory. University of Chicago Press.

Müller, J. (2011). Albrecht Dürer's peasant engravings: A different Laocoön, or the birth of aesthetic subversion in the spirit of the Reformation. Journal of Historians of Netherlandish Art, 3(1), 1-19.

Sjöholm, C. (2013). Lessing's Laocoön: Aesthetics, affects and embodiment. The Nordic Journal of Aesthetics, $46,18-33$.

Virgil (1952). The Aeneid. Trans. C. Day Lewis. Oxford University Press.

Winckelmann, J. (2006). History of the art of antiquity. Trans. H. Malgrave. Getty.

Wright, J. M. (2004). Blake, nationalism, and the politics of alienation. Ohio University Press. 